\title{
THE THEORY AND PRACTISE OF USING REPRESENTATIONAL MATERIALS IN LANGUAGE TEACHING
}

\author{
NICHOLAS ONYANGO OLOO \\ Department of Languages, Linguistics and Literature, Jaramogi Oginga Odinga University of Science and \\ Technology, Kenya
}

DOI: 10.46609/IJSSER.2021.v06i01.007 URL: https://doi.org/10.46609/IJSSER.2021.v06i01.007

\section{Introduction}

English is regarded as the language of communication worldwide. Nunan (2001:605) observes that today English permeates every part of our social spheres. 'It is the language of business, technology, science, internet, and even sports.'

The primary objective of teaching English as a second or as a foreign language should be to develop the learners' communicative competence, which is, mastering the use of English in a variety of situations, social contexts and professional areas. English should therefore be taught in a way that learners are able to master and internalize practical linguistic skills for communication purposes in their daily lives. (Lumala 2008)

\section{English teaching materials}

In most (ESL/EFL) contexts, teachers have always resorted to using prescribed course books in teaching. However, many of these texts function on a wholly referential level. Referential language communicates at only one level which is informational. Lau $(2002: 172,178)$ points out that these books contain materials that have neglected the interest and the needs of the learner as they are 'boring and referential but not imaginative and representational.' Referential texts simply transmit information and the students are not given the opportunity to interact with the text to try and find out what it 'could or might mean because there is only one thing it can mean' (Jones, 2003). The words of the referential text 'mean what they say, no more and no less.' (McRae, 1996:17)

Since all languages are representational, and 'a purely referential text rare' (McRae 1996:19), the use of referential texts therefore denies the learners the interpretive and imaginative skills they require to become proficient users of English. (Jones, 2003:1). This is supported by McRae who writes that: 


\section{International Journal of Social Science and Economic Research}

ISSN: $2455-8834$

Volume:06, Issue:01 "January 2021"

'The development of language competence in a learner has to allow for imaginative interaction, for an element of creativity, and for an affective element of subjective, personal development, all of which go well beyond the limitations of referential language'(McRae, 1996:19).

Lewis (1993: 48) also states 'understanding is not a binary, yes/no concept; more or less, meaning is created by an interpersonal process of interpretation, negotiation and response.' These statements emphasize the importance of learner's active participation in creating meaning in a text which can only be provided by the use of representational materials in teaching (McRae 1991/97:5).

\section{Representational materials}

McRae (1991:3) defines representational materials as texts which engage the imagination of the learner in interpreting meaning. This is contrasted to referential materials which are basically informational and require very little thinking from the learner (McRae, 1991:4, 5). Texts which simply transmit information and do not tax the reader's imagination such as public notices, recipes are said to be referential. In order to be easily understood, most reading texts found in English textbooks are referential.

Representational materials are any texts with imaginative content which engage the learners in imaginative interaction, reaction and response. Representational texts offer a process based approach to learning. It therefore follows that for any text to be considered representational, it must involve the reader in an interactive and imaginative interpretation of meaning (McRae 1991/97:4).

Teachings using representational materials develop what McRae calls the fifth language skill, which is "thinking in English"(McRae, 1991, p. 5). Representational texts can be used in teaching the four language skills and the additional fifth skill of thinking and processing (McRae, online). Thinking in English enables the learners to have a greater ability to understand 'how language works rather than what it says and on how it means rather than what it means'(McRae online).When the learners acquire this capacity to think in the target language they become effective and better users of English (Jones 2003).

Representational materials can be literary or non-literary. Literary materials are found in literary texts; poetry, drama, songs and short stories, and non-literary in non-fictional texts for instance advertising materials, newspaper articles. Both literary and non-literary texts can provide the required representational materials to be used in a language classroom.

In this essay I am going to discuss how representational materials from literary texts can be used in classroom teaching. I will begin by discussing why literary texts are considered representational then show how they can be used in language teaching. 
International Journal of Social Science and Economic Research

ISSN: 2455-8834

Volume:06, Issue:01 "January 2021"

\section{Literary texts as representational materials}

Literary texts are representational rather than referential (McRae 1994).The representational language of literary texts involves the learners and engages their emotions, as well as their cognitive faculties. These kinds of literary texts which are used in language teaching are what McRae refers to as' literature with a small l' (McRae, 1996:17).Carter and McRae (1996) point out that literary text contain:

'culturally- rooted language which is purposefully patterned and representational which actively promotes a process of interpretation and encourages a pleasurable interaction with negotiation of its meaning' (Carter and McRae,1996).

Literary texts have proved to be very resourceful in language teaching because they stimulate the mind by offering students examples of real language use. (Satu, 2007:30)

Different genres of literature can be valuable resource material for language teaching. Poems, plays, short stories and novels offer a rich source of language teaching materials. The teacher can design learning activities based on literary texts to teach the basic language skills- reading, writing, listening and speaking in addition to language areas such as grammar and vocabulary (Murat, 2005:57).

\section{Teaching strategies using representational materials}

Language-based approaches (LBA) are the most effective strategies in language teaching using representational materials. This model proposes integration between language and literature in which students can improve their language proficiency using literature as a resource in learning. The approach offers a variety of activities which give the learners the opportunity to participate actively in the process of working out the interpretation of texts. It is a student-centered, activity based and process oriented approach to language teaching (Ganakumaran, 2002, Carter, 1996:3).

Representational materials encourage dynamic learning in which the learners are actively and personally involved. As stated by McRae (1996:31):

'arguing and discussing are useful in working with representational materials.......Structured discussion and debate, group work to reach agreed opinions, and balanced monitoring of divergent views are required.'

The learning activities using representational texts must vary to include the four linguistic skills of listening, speaking, reading and writing as well as developing critical thinking (Nasr 2001:352). The questions should allow learners to think imaginatively and respond freely (Lau 2002:176) 


\section{International Journal of Social Science and Economic Research}

ISSN: $2455-8834$

Volume:06, Issue:01 "January 2021"

The teacher's role in this process is more of a provider of resources and a motivator. The teacher has to guide, correct and advise (Lau 2002:172). 'The teacher will often have to act as referee' (McRae 1996:31) as the learners interact with the text.

Some language activities which can be used to teach using representational materials include; cloze procedure, summary writing, prediction, role play, reading aloud, paraphrasing and rewriting (Carter and Long 1991, Carter1997).

Before discussing how some of these activities can be used with representational materials, it is important to look at the framework within which this process works.

\section{Pedagogical Framework}

McRae (1991:95) developed a framework that can be used to guide the process of teaching using representational materials. This framework is a checklist which identifies all the linguistic features of a text. The framework proposes that analysis with focus on textual components will act as the bridge from the 'referential' to 'representational' textual meaning (Ganakumaran, 2003).

This means that teachers can develop activities that direct students' attention to these features so that students may understand how the language of the texts works and what messages it attempts to reveal. (Ganakumaran, 2003:3).The framework is illustrated in the diagram over-leaf.

\section{The checklist}

\begin{tabular}{|l|l|}
\hline Lexis & words \\
\hline syntax & how words are put together \\
\hline cohesion & linking mechanism within a text \\
\hline phonology & how the text sounds \\
\hline graphology & the look, layout and visual effects of a text \\
\hline semantics & the study of meaning and how meaning is achieved \\
\hline dialect & Spoken variants of standard English \\
\hline register & tone dependent on context /degree of formality \\
\hline period & when the text was written, for whom (archaism etc) \\
\hline function & what the text does, /aim/ the message in the text \\
\hline
\end{tabular}


International Journal of Social Science and Economic Research

ISSN: 2455-8834

Volume:06, Issue:01 "January 2021"

This checklist offers a whole range of tasks and questions that go beyond function which many English textbooks do. For example, students might be asked to discuss what words in text could mean (semantics), how they think a sentence in a text sounds if read aloud (phonology), or to find and discuss the old-fashioned language (period) (Jones 2003).

\section{How representational materials can be used in language teaching}

McRae advises that representational materials should not be introduced 'cold'

They should be introduced with some 'preliminary preparation. This is what McRae refers to as the' pre-presentation phase' (McRae, 1991:97).He reminds teachers that the pre-presentation of an imaginative text enables the learners to understand the linguistic benefits which they stand to gain from reading the text.

Discussed below are some language-based activities which can be used in teaching using representational materials. In this essay, these activities are generated by using a poem, a short story and a play.

\section{Reading aloud}

Reading aloud is reading in a voice loud enough to be heard by others. This activity is useful in developing the student's listening and speaking abilities. A poem is the most appropriate for this activity because a poem is meant be recited.

Reading a poem aloud is effective in teaching pronunciation. The learners can also practice how to use other non-linguistic features such as pause, stress and intonation in speech. The activity can be conducted with students working in small groups.

\section{Procedure}

Students are given the poem (refer to Appendix 1) and working in groups practice how to read it aloud. As they rehearse, they are expected to pay attention to aspects of voice quality such as loudness/softness, speed of delivery- fast/ slow and pitch variation- high/low. They should also consider other articulation factors; stress, pause and intonation in their reading.

After a period of discussion, each group is expected to appoint a member who will read the poem to the class. When all the groups have presented, a class discussion can be held to evaluate all the presentations and decide on the best performance based on the following:

a) Manipulation of voice

b) Use of stress, intonation, and pause

c) Pronunciation of words. 
International Journal of Social Science and Economic Research

ISSN: 2455-8834

Volume:06, Issue:01 "January 2021"

The teacher's role in this activity is to correct the students' errors in the areas mentioned above. This activity fits into the phonology component in McRae's framework.

\section{Gap -Filling/Cloze procedure}

Gap filling is an effective strategy for teaching vocabulary.

This activity works on the principle of expectancy and prediction. Carter and Long explain that the 'basic idea behind this activity is to bring aspects of language and form to the attention of learners while making them explore their relation to the textual meaning'

( carter and Long,1991 quoted in Ganakumaran,2003:5). The activity works on the principle of justification which allows for rationalizing and supporting selections made by the learners, based on the context of the sentence (Ganakumaran,2003:3).

Before making what they consider to be the correct choice, the learners have to evaluate the different effects of one word over another by considering the grammatical, semantic and in the case of poetry, the sound patterns (Carter and Long 1991:87).

This activity requires students to pay attention to lexical choice and collocation. Students have to read the whole text before making their choices.

\section{Procedure}

In this activity, students can either work individually or in pairs.

The students are given a poem with a blank in each line (refer to Appendix 2)

At the end of each line the students are provided with two choices to fill the blank with.

Students are reminded that when selecting words to fill the blanks they should pay attention on how their choice relates to other words in the line and the whole poem.

At the end of the activity a class discussion can be held to consider the choices made by students.

This activity fits with the lexical, phonology and semantic component in McRae's model.

\section{Jig-saw Reading}

McRae (1991/97: 111) describes this method as a situation:

'whereby students, singly or in groups read separate sections of a text and the exchange information on it- usually through question and answer or oral summary- in order to build up the complete picture'( McRae 1991/97: 111).

This method works with the re-ordering of texts that have been scrambled. It demands that the students look closely at the language of the texts and this stimulates student interaction in solving the 'puzzle' (Carter and Long 1991:71). The term 'jigsaw' is appropriate because indicates ' a 
International Journal of Social Science and Economic Research

ISSN: 2455-8834

Volume:06, Issue:01 "January 2021"

series of small increments which, when added together, will complete the picture...' (Carter and Long 1991:71). The activity can be used with a poem or a narrative text.

\section{Procedure}

The students are given jumbled up paragraphs of a narrative which they are expected to reorganize. (Refer to Appendix 3) . They are required to discuss within their groups how to rearrange the paragraphs in what they consider to be the correct order.

In this activity, learners are required to reorganize the paragraphs to make the story coherent. The students should pay attention to logical cohesion and general organization of the narrative to successfully complete this exercise.

After a few minutes, each group is required to present and justify their choice for the sequence in which the paragraphs appear in the story. This can be followed by a class discussion on the features in the text that can help in the re-ordering the paragraphs.

The teacher can then give the correct sequence as it appears in the original story so that the students can compare with their own.

The activity requires the students to focus on textual and semantic clues in order to come up with what they believe to be the correct sequence. It also helps students to understand the organization of a narrative.

This activity is related to syntax, cohesion and function component in McRae's model.

\section{Summary writing}

This exercise involves extracting the main points from a text and summarizing the information required within an approximate word limit. Writing a summary is a practical task that allows learners to read, understand and write the main ideas in a text using fewer words than those used in the original text. The students can either be asked to write a summary of the whole text or some specific information required from the text.

This activity is used to teach students how to construct sentences.

\section{Procedure}

Each group should read the text given, note down the main points and thereafter write the summary sticking to the word limit given. (Refer to appendix 4)

Each group should read out its summary to the whole class and the class expected to comment and discuss on the quality of work presented. The assessment should be guided by the following factors:

a) Has the summary captured the content of the original text? 


\section{International Journal of Social Science and Economic Research}

ISSN: $2455-8834$

Volume:06, Issue:01 "January 2021"

b) Is it readable and coherent?

c) Are the words and expressions appropriately used?

d) Is the summary written within the required number of words?

The teacher should correct and offer advice on the student's presentation.

This activity covers lexis, syntax, cohesion, graphology, semantics and function aspects in McRae's model.

\section{Paraphrasing and Re-writing}

Carter (1997:78) states that this activity 'involves student re-writing stretches of discourse to change its communicative value.' Re-writing enables students to understand how information is structured in different texts (Carter 1997:78).It also provides the learners with the opportunity to practice writing skills in addition to developing their grammar and vocabulary. (Lau 2002:178)

\section{Procedure}

This activity can be done individually or in groups. It requires the students to rewrite the information in the dialogue paraphrasing it into prose (Refer to appendix 5).

A student from each group should be called upon to read their story. Other members of the class can comment on the interpretation of the play and the organization of the story. A class discussion guided by the teacher should follow to exchange ideas and interpretations of the different groups. Rewriting allows students to re-evaluate their interpretations of the play and gives the teacher access to the mental perceptions that students have of the play.

Paraphrasing involves expressing the meaning of something written or said using words which will make it easier to be understood. Texts written in old English such as the one used here (Merchant of Venice), can provide very good material for paraphrasing activity. Students are asked to paraphrase the words of certain characters to a language which can easily be understood. (Appendix 5 question 2)

In this context, these activities are related to lexis, syntax, cohesion, semantics, and graphology, period and function aspects in McRae's model.

\section{Role play}

Role play apart from spicing up the lessons is useful in developing the learner's listening and speaking skills and building their confidence. Livingstone states:

'Role play is therefore a classroom activity which gives the student the opportunity to practice the language, the aspects of role behaviour and the actual roles he may need outside the classroom' (Livingstone, 1983:6). 


\section{International Journal of Social Science and Economic Research}

ISSN: $2455-8834$

Volume:06, Issue:01 "January 2021"

Dialogue from a play is a good source of material for this activity. It is through the use of drama that learners become familiar with grammatical structures in context and also learn about how to use language to express and inform (Sujata, 2009:78).

Role play is considered a successful technique for teaching speaking and listening skills because it gives the students the opportunity to practice the language. The teacher's role in this exercise is to correct the students' pronunciation and show them how to speak. It develops oral expression and interpretation skills as learners use language to describe perceptions, emotions, and reactions presented in the dialogue.

\section{Procedure}

In this context, the students' are given a piece of dialogue from a play to act out the roles of the characters. Each member in a group takes up the role of a character of his/her choice. They are asked to come up with a creative presentation of the play. The meaning and the emotions in the play have to be expressed as clearly as possible. Each group is asked make its presentation within a given time limit.

Each student is given an evaluation sheet to assess the performance of the groups but not their own (Appendix 6)

The evaluation is based on the following criteria:

a) Clarity of performance

b) Accuracy with regards to the content of the play

c) Ability to represent the character's emotional state.

At the end of the performance, the students are invited to comment on the performance based on the evaluation criteria and with reasons pick on the best performance.

This activity works on the semantic and function components in McRae's component.

\section{Conclusion}

The use of representational materials in teaching helps to develop the learners' critical thinking which enables them to become effective and proficient users of English.

These materials should be selected judiciously and wisely taking into account factors such as their relevance to the lesson objectives, interest of the learners, learners' linguistic level, time available, and cultural difficulty. It is important that the kind of tasks and activities designed with representational texts should focus on how meaning is created in the text and not just what it means. McRae's checklist should be used to guide this process.

There is also need to raise awareness and equip the teachers with knowledge, skills and techniques of using these materials in teaching. The appropriate selection and practical usage of 
representational materials offer one of the best methods of language teaching because they are interesting, motivating and help students to become imaginative and better learners. (Mushfeka, 2008:189,190).However, this does not mean that referential materials should be discarded but that their use should precede and form the background for the use of representational one.

\section{Appendixes}

Appendix 1

Read the following poem aloud.

The secret of the machines

We were taken from the ore- bed and the mine

We were melted in the furnace and the pit-

We were cast and wrought and hammered to design

We were filed and tooled and ganged to fit

Some water, coal and oil is all we ask

And a thousandth of an inch to give us play:

And now if you will set us to our task,

We will serve you four and twenty hours a day!

We can pull and hand and push and lift and drive,

We can print and plough and weave and heat and light,

We can run and jump and swim and fly and dive,

We can see and hear and count and read and write! And so on

\section{Appendix 2}

By Rudyard Kipling

Read the poem carefully and fill the blanks with appropriate words provided in the brackets 
We were taken from the ore- bed and the , (hole, mine)

We were in the furnace and the pit(burnt, melted)

We were cast and wrought and hammered to , (design, shape)

We were filed and and ganged to fit, (bent, tooled)

Some , coal and oil is all we ask (soil, water)

And a thousandth of an inch to give play: (them, us)

And now if you will set us to our (work, task)

We will serve you four and twenty hours a (minutes, day)

We can pull and hand and and lift and drive, (squeeze, push)

We can print and plough and weave and heat and , (light, brighten)

We can run and jump and swim and fly and (rotate, dive)

We can see and and count and read and write! And so on. (smell, hear)

\section{Appendix 3}

The following paragraphs have been jumbled up. Read and reorganize the paragraphs to complete the story.

A. My grandfather lowered his head for a moment, then looking across at the wide expanse of field, he said: 'Do you see it stretching out from the edge of the desert up to the Nile bank? A hundred feddans. Do you see all those date palms? And those trees, acacia, and sayal? All this fell into Masood's lap was inherited by him from his father.'

B. One day I asked him about our neighbour Masood.I said to my grandfather: I fancy you don't like our neighbour Masood?

C. My grandfather then continued: 'Yes my boy, forty years ago all this belonged to Masood-two thirds of it is now mine.'

D. 'I didn't own a single feddan when I first set foot in this village.Masood was then the owner of all these riches. The position has now changed now, though, and I think that before Allah calls to Him I shall have bought the remaining third as well.'

E. This was news to me for I had imagined that the land had belonged to my grandfather ever since God's Creation. 
International Journal of Social Science and Economic Research

ISSN: 2455-8834

Volume:06, Issue:01 "January 2021"

F. To which he answered, having rubbed the tip of his noise:' He's an indolent man and I don't like such people.'

G. Taking advantage of the silence which that had descended upon my grandfather, I turned my gaze from him to the vast area defined by his words.

I don't care,'I told myself, who owns those date palms, those trees or this cracked earth-all I know is that it's the arena of my dreams and my playground.'

The correct order is $(\mathrm{B}, \mathrm{F}, \mathrm{A}, \mathrm{G}, \mathrm{C}, \mathrm{E}, \mathrm{D})$

\section{Below is the original text}

One day I asked him about our neighbour Masood.I said to my grandfather: I fancy you don't like our neighbour Masood?

To which he answered, having rubbed the tip of his noise:' He's an indolent man and I don't like such people.'

My grandfather lowered his head for a moment, then looking across at the wide expanse of field,he said: 'Do you see it stretching out from the edge of the desert up to the Nile bank? A hundred feddans. Do you see all those date palms? And those trees,acacia,and sayal? All this fell into Masood's lap was inherited by him from his father.'

Taking advantage of the silence which that had descended upon my grandfather, I turned my gaze from him to the vast area defined by his words.

I don't care,'I told myself, who owns those date palms, those trees or this cracked earth-all I know is that it's the arena fro my dreams and my playground.'

My grandfather then continued: 'Yes my boy, forty years ago all this belonged to Masood-two thirds of it is now mine.'

This was news to me for I had imagined that the land had belonged to my grandfather ever since God's Creation.

'I didn't own a single feddan when I first set foot in this village.Masood was then the owner of all these riches. The position has now changed now,though, and I think that before Allah calls to Him I shall have bought the remaining third as well.'

\section{A handful of dates by Tayeb Salih (Sudan)}




\section{Appendix 4}

Read the extract below and in not more than 90 words summarize Antonio's speech.

SHYLOCK: I cannot find' $t$ is not in the bond.

PORTIA (To Antonio) You merchant, have you anything to say?

ANTONIO But little, I am armed and well prepared

Give me your hand, Bassanio;fare you well,

Grieve not that I am fall'n to this for you,

For herein Fortune shows herself more kind

Than is her custom. It is still her use

To let the wretched man outlive this wealth,

To view with hollow eye and wrinkled brow

An age of poverty: from which ling' ring penance

Of such misery doth she cut me off.

Commend me to your honourable wife;

Tell her the process of Antonio's end,

Say how I loved you, speak me fair in death

And when the tale is told, bid her be judge

Whether Bassanio had not once a love

Repent but you that you shall lose your friend

And he repents not that he pays your debt

For if the Jew do cut but deep enough

I'll pay it instantly, with all my heart 
BASSANIO Antonio,I am married to a wife

Which is as dear to me as life itself?

But life itself, my wife, and all the world,

Are not with me esteemed above thy life

I would lose all, ay, sacrifice them all

Here to this devil, to deliver you.

PORTIA Your wife would give you little thanks for that

If she were by to hear you make the offer

GRATIANIO I have a wife who I protest I love-

I would she were in heaven, so she could

Entreat some power to change this currish Jew

NERRISA ' $\mathrm{T}$ is well you offer it behind her back;

The wish would make else an unquiet house.

SHYLOCK (Aside)

These be the Christian husbands! I have a

Daughter-

Would any of the stock of Barrabas

Had been her husband, rather than a Christian

(Aloud) We trifle time; I pray thee pursue sentence.

\section{Appendix 5}

Read the extract from the play and answer these questions

a) In about 200 hundred words, write the story in this extract. 
International Journal of Social Science and Economic Research

ISSN: 2455-8834

Volume:06, Issue:01 "January 2021"

\section{b) Rewrite the following expressions used in the extract in Standard English.}

i. To let the wretched man outlive this wealth,

ii. Are not with me esteemed above thy life

iii. We trifle time; I pray thee pursue sentence.

\section{Appenix 6}

Watch the performances of the play presented by each group evaluate and award marks for each of the group's presentation as follows:

a) Clarity of performance $4 \mathrm{mks}$

b) Accuracy to the play $3 \mathrm{mks}$

c) Ability to present the character's emotional state $3 \mathrm{mks}$

\section{References}

Carter, R. (1997). Investigating discourse. London: Routledge

Carter, R. and McRae, J. (Eds. ). (1996). Language, literature and the learner. Harlow: Longman.

Carter, R.and Long,M. (1987).The Web of words: Exploring Literature Through Language. Cambridge: Cambridge University Press.

Carter, R. and Walter N. (1990).Seeing Through Language, Oxford, Blackwell

Carter, R.and Long,M. (1991).Teaching Literature.Harlow:Longman.

Fan-Ping, T. (2010).Introducing Literature to an EFL classroom: Teacher's presentations and student's perceptions. Journal of language Teaching and Research, January 2010, 1(1),pp 53-65.

Ganakumaran, S. (2003).Linguistic Pathways to the study of Literature in the Malaysian ESL Context.GEMA Online Journal of Language Studies..3(1) 2003.

Jones,C. (2003) Using Representational reading texts in the EFL classroom. British Council, Lau,G.(2002).The use of literary texts in primary level language teaching in Hong Kong. Kong Teachers Center journal, 1, pp 172-179. 
International Journal of Social Science and Economic Research

ISSN: 2455-8834

Volume:06, Issue:01 "January 2021"

Lewis, M. (1993). The lexical approach: The state of ELT teaching and a way forward. Hove: Language Teaching Publications.

Livingstone, C. (1983). Role play in language learning. Longman Group Limited.

McRae, J.1991/97.Literature with a small '1'.London:Macmillan , 1996, “Representational Language Learning: From Language Awareness to Text

Awareness" in Carter and McRae, Language Literature and the Learner. Pp.16-40.

McRae.J. and M.E.Vethamani.1998.Now Read On.London.Routledge.

Nunan,D.(2001).Action Research in language education. In Hall and Hewings, 2001:197-207.

Murat,H. (2005).Teaching English through Literature. Journal of Language and Linguistic

Studies.

Mushfeka,D.(2008).Literature- One of the best ways of teaching, Daffodil International University, Journal of Business and Economics, 3(1),pp 189-197.

Sujata,R.(2009).Teaching language through literary texts in ESL classroom. Language in India, 6 June 2009 pp 72-80. 